\author{
University of Texas Rio Grande Valley \\ ScholarWorks @ UTRGV
}

$7-2011$

\title{
Does Inflation Targeting Matter for Output Growth? Evidence from Industrial and Emerging Economies
}

Andre V. Mollick

The University of Texas Rio Grande Valley

Rene Cabral

Francisco G. Carneiro

Follow this and additional works at: https://scholarworks.utrgv.edu/ef_fac

Part of the Finance Commons

\section{Recommended Citation}

Mollick, André Varella, René Cabral, and Francisco G. Carneiro. "Does Inflation Targeting Matter for Output Growth? Evidence from Industrial and Emerging Economies.” Journal of Policy Modeling 33, no. 4 (July 2011): 537-51. https://doi.org/10.1016/j.jpolmod.2011.03.010.

This Article is brought to you for free and open access by the Robert C. Vackar College of Business \& Entrepreneurship at ScholarWorks @ UTRGV. It has been accepted for inclusion in Economics and Finance Faculty Publications and Presentations by an authorized administrator of ScholarWorks @ UTRGV. For more information, please contact justin.white@utrgv.edu, william.flores01@utrgv.edu. 


\title{
Does Inflation Targeting Matter for Output Growth? Evidence from Industrial and Emerging Economies
}

\author{
André Varella Mollick \\ Department of Economics and Finance \\ University of Texas - Pan American \\ 1201 W. University Dr. \\ Edinburg, TX 78539-2999, USA \\ E-mail: amollick@utpa.edu \\ Tel.: +1-956-316-7135 and fax: +1-956-381-2687. \\ René Cabral Torres \\ Escuela de Graduados en Administración Pública y Política Pública \\ Tecnológico de Monterrey, Campus Monterrey \\ Ave. Rufino Tamayo, Garza García, NL, México. CP. 66269 \\ E-mail: rcabral@itesm.mx \\ Tel.: +52-81-8625-8347 and fax: +52-81-8625-8385 \\ Francisco G. Carneiro \\ The World Bank \\ Operations Policy and Country Services - OPCS \\ 1818 H Street, NW, Washington DC 20433, USA \\ Email: fcarneiro@worldbank.org \\ Tel: +1-202-473-0360
}

Keywords: Economic Growth, Globalization, Inflation Targeting, Panel Data Methods.

JEL Classification Numbers: F31, F32, F33, F34. 


\section{Introduction}

A significant amount of literature has recently studied the effects of inflation targeting (IT) on price stability in industrial and emerging economies. ${ }^{1}$ While the conclusion might still be debatable, the partial consensus seems to suggest that IT has been effective on achieving price stability in emerging market economies but not in industrial economies. Nonetheless, according to its supporters, the potential benefits of IT are not limited to price stability. For instance, once a low, stable inflation is achieved and credibility is enhanced, IT could lead to a reduction of the output losses associated with disinflation. According to this view, "a case can even be made that inflation targeting promotes real economic growth in addition to controlling inflation.” Mishkin (1999, p. 597)

A recent literature has explored whether "globalization" (broadly understood as the growing volumes of trade and financial flows) helps economic growth. ${ }^{2}$ Bekaert et al. (2005) demonstrate that equity market liberalization (foreign investors are allowed to transact in domestic securities and vice versa) does increase economic growth. They find

\footnotetext{
${ }^{1}$ Among the studies that empirically assess the effects of IT on price stability across industrial countries see, for instance, Johnston (2002), Newman and von Hagen (2002) and Ball and Sheridan (2005). For empirical assessments among emerging markets, refer to Fraga et al. (2004), Lin and Ye (2008) and Gonçalves and Salles (2008), among others. There are also studies that assess emerging and industrial economies together, such as: Vega and Winkerlried (2005) and those that examine both groups separately and jointly (Mishkin and Schmidt-Hebbel, 2007).

${ }^{2}$ See Mishkin (2008) for a survey and a positive view. A similar characterization of globalization has been put forward recently by Kose et al. (2008) on the rising trade and financial linkages. See also Wynne and Kersting (2007) for the impact of trade, financial or labor openness on inflation under a cross-section approach, as well as evidence on the response of inflation to output gap as becoming less responsive with globalization. Sachsida et al. (2003) document a negative relation between inflation and trade openness for 152 countries over 1950-1992. Discussing the currency and financial crises in the late 1980s and 1990s, Kose et al. (2006, p. 7) mention that "there is a widely held perception that developing countries that opened up to capital flows have been more vulnerable to these crises than industrial economies, and have been much more adversely affected. These developments have sparked a fierce debate among academics and practitioners on the costs and benefits of financial globalization. This debate has intensified and become more polarized over time, in contrast to the debate on trade liberalization, which has more or less moved toward a consensus."
} 
that equity market liberalization leads to an approximate $1 \%$ increase in annual real per capita GDP growth. Alfaro et al. (2004) find that countries with well-developed financial markets gain significantly from FDI and Alfaro and Hammel (2008) identify that stock market liberalizations are associated with a significant increase in the share of machinery and equipment and, therefore, economic growth. This body of evidence suggests that any empirical work to explain GDP growth over time that overlooks financial or trade measures is fundamentally flawed.

A major advance to study globalization has been the comprehensive dataset made available by Lane and Milesi-Ferretti (2007). They have constructed estimates of external assets and liabilities for 145 countries for 1970-2004 and have documented the increasing importance of equity financing and the improvement in the external position for emerging markets, as well as the differing pace of financial integration between advanced and developing economies. This dataset supersedes own measures of financial globalization built by researchers so far. ${ }^{3}$

Although there is no theoretical and empirical consensus about the overall impact of IT on output growth, it is well accepted that all IT central banks "not only aim at stabilizing inflation around the target but also put some weight on stabilizing the real economy” (Svensson, 2007, p. 1). ${ }^{4}$ Recent theoretical models point at mixed effects. One could mention the ambiguous effects of inflation targeting on growth provided by Gupta (2006), the suboptimal nature of IT (dominated by nominal income growth) put forward

\footnotetext{
${ }^{3}$ Albuquerque et al. (2005), for instance, construct a globalization measure that equals the share of explained variation in direct investment attributable to global factors. They show that the measure has increased steadily for developing and developed countries alike. See also Edison et al. (2004) for a detailed description of different measures of capital account openness.

4 Bernanke (2003) also considers that the idea of IT focusing exclusively on control of inflation and ignoring output and employment objectives is a misconception. He suggests that "short-run stabilization of output and employment is more effective when inflation expectations are well anchored" through the constrained discretion that provides an IT regime.
} 
by Kim and Henderson (2005), or the negative output and employment effects reported by Cordero (2007).

At the empirical front, Svensson (2007, p. 3) states that "there is no evidence that inflation targeting has been detrimental to growth productivity, employment, or other measures of economic performance”, a view supported by Dotsey (2006) in his comparison of 5 industrial countries that have been targeting inflation for at least 10 years and 6 non-IT industrial countries. Similarly, Ball and Sheridan (2005) find no meaningful effect of IT on price stability, exchange rate volatility, long-run interest rates or output growth when they employ a cross section difference-in-difference model to explore the effects of IT in a sample of 20 OECD countries.

Also, regarding the more fundamental empirical relation between inflation and economic growth, the existing body of evidence does not reach a consensus but does establish important differences between industrial and emerging economies. For instance, using data for 12 Latin American countries during the period 1950-1985, De Gregorio (1993) documents statistically significant and negative effects of average inflation on growth. Meanwhile, recent evidence by Pollin and Zhu (2005) for OECD countries shows that no clear pattern emerges at all between inflation and output growth.

Although the general issue of collateral benefits having an impact on GDP has been conjectured by Kose et al. (2006), we are not aware of empirical work focusing on any benefits of monetary policy jointly with advances in the globalization of financial flows. The availability of the Lane and Milesi-Ferretti (2007) data and of recent theoretical constructions by Kose et al. (2006) and Evans and Hnatkovska (2007) make the proposed research route worth exploring. In this paper we examine the effects of IT 
on income per capita growth using separate samples of industrial and emerging economies that have been facing increasing trade and financial integration. We do this by integrating the globalization wave to the potential output benefits of IT practices. In addition, accounting for globalization in our analysis is important because the more conducive environment for economic growth associated with an increase in the trade or financial flows across the world may be reduced if the inflation commitment is too strong in the case of IT followers. Under this scenario, we would have very high output costs of inflation. On the other hand, a very stable inflation environment is thought to be good for economic growth since firms may plan their investment decisions more carefully. The net impact is, however, an empirical issue.

The results obtained in this paper provide additional support to earlier findings in the literature of a positive relationship between financial globalization and real output growth for both industrial and emerging economies. In addition, when exploring the adoption of inflation targeting (IT) regimes, we find (i) that soft-IT regimes have been marginally beneficial for industrial economies and also (ii) conclusive evidence of positive effects of fully-fledged IT regimes on income per capita across both emerging and industrial economies. One interpretation of our results is that the disinflation process of the last two decades has made the output benefits far outweigh the output costs of setting high interest rates in order to control inflation and attract capital flows in a global world.

The remainder of the paper is organized as follows. Section 2 describes the main sources of our data, the industrial and emerging countries in each sample, the year in which they adopted IT and presents some descriptive statistics. Section 3 discusses the 
theoretical foundations of our empirical model. Section 4 explains the econometric techniques employed and presents the results of our estimations under random effects and dynamic panel data methods. Section 5 summarizes the main findings and implications of this study.

\section{The Data}

The main sources of our data are the IMF's International Financial Statistics database and the multi-country dataset on foreign assets compiled by Milesi-Ferreti and Lane (2007). Data for GDP per capita (our dependent variable), investment and trade are obtained from the former source. Financial globalization indexes were constructed based on Milesi-Ferreti and Lane database. Our dataset initially spans from 1970 to 2004. We decide, however, to shorten the sample and concentrate on the period from 1986 to 2004 following the suggestion by Kose et al. (2006) and Kose et al. (2008) that the recent wave of financial globalization started in the mid-1980s.

Rather than assessing together industrial and emerging markets (EMEs), we compare the performance of both groups separately. In our view, comparing the performance of emerging economies with that of industrial economies might not be prudent. Firstly, developing economies and industrial economies started to experiment with IT at different times. Except for Chile and Israel, most EMEs started to target inflation in the second half of the 1990s, while almost every targeter industrial economy adopted the regime in the early 1990s. Secondly, because there might be long lags until the full effects of greater credibility---associated with the adoption of IT---are fully felt in the real economy, it is possible that comparing emerging vis-à-vis industrial economies 
might be biasing the aforementioned assessments. Thirdly, there are fundamental institutional differences between industrial and emerging economies, such as less developed financial markets, weak fiscal institutions, lower credibility of financial institutions, liability dollarization, and vulnerability to sudden stops of capital inflows, which make it more difficult to design and implement effective monetary policies in EMEs (Mishkin, 2003). Due to these factors, shocks to EMEs are more persistent and recurrent than in industrial economies. As a result, comparing the performance of EMEs and industrial countries together might well be disadvantageous for the former group and make the effect of adopting an IT regime imperceptible. ${ }^{5}$

In order to check the impact of IT on real per capita output growth of industrial and emerging countries, we need to be as precise as possible regarding the implementation of the regime. Vega and Winkelried (2005) examined several studies that dated IT policies across countries and concluded that the year of IT adoption for developed economies is much less controversial than in developing countries. Following the study by Vega and Winkelried (2005), who found that IT has helped in reducing the level and volatility of inflation in the countries that adopted it, we define two dummy variables: ITsoft when there is a simple announcement of a numerical target or a nonbinding statement that a country is switching to IT, and ITfull for fully fledged IT adoption in which there exists a public target and a commitment to it as a unique nominal

\footnotetext{
${ }^{5}$ Henry (2007) actually claims that one of the reasons why the literature on FG tends to find negligible impacts of financial liberalization on output growth is precisely because developing and industrial economies are grouped together in cross-sectional regressions.
} 
anchor. In both cases, the dummy variables are 1 at the adoption date and thereafter; 0 otherwise $^{6}$.

[Table 1 here]

We have a total of 55 economies in our sample, 22 are industrial and 33 emerging economies. From those, 23 have adopted IT, 13 are industrial economies and 10 emerging markets. This implies that the incidence of IT is observed in little less than half of the countries in the sample. Table 1 list the economies in the sample, the years in which they adopted IT, their per capita income average growth rates, their average investment-to-output ratios and the average of their indexes of trade and financial globalization. Our first measure of globalization is the traditional trade openness (TO), which is calculated as total trade, the sum of exports and imports, over GDP. Following Lane and Milesi-Ferretti (2007), we employ two alternative measures of financial globalization. First, a measure of international financial integration (IFI) with respect to GDP: $\mathrm{IFI}_{\mathrm{it}}=\left(\mathrm{FA}_{\mathrm{it}}+\mathrm{FL}_{\mathrm{it}}\right) / \mathrm{GDP}_{\mathrm{it}}$, where: $\mathrm{FA}(\mathrm{FL})$ denotes the stock of external assets (liabilities). Second, a financial integration measure also with respect to GDP and based on portfolio equity and FDI stocks: $\mathrm{GEQ}_{\mathrm{it}}=\left(\mathrm{PEQA}_{\mathrm{it}}+\mathrm{FDIA}_{\mathrm{it}}+\mathrm{PEQL}_{\mathrm{it}}+\mathrm{FDIL}_{\mathrm{it}}\right) / \mathrm{GDP}_{\mathrm{it}}$, where: PEQA (PEQL) denotes the stock of portfolio equity assets and FDIA (FDIL) denotes the stock of their direct investment assets (liabilities).

In Table 1 the countries with the largest rates of per capita growth across emerging and industrial countries are, respectively, China (8.41\%) and Ireland (5.47\%). Meanwhile, those with the lowest growth rates are Venezuela (0.005\%) and Switzerland (0.89\%). On average, the group of emerging markets presents slightly higher investment-

\footnotetext{
${ }^{6}$ Previous literature assessing the effects of IT on price stability has also made use this alternative classification of partial and full IT. See, for instance, Corbo et al. (2002) and Roger and Stone (2005).
} 
to-output ratio (21.36\% versus $20.99 \%)$ and per capita GDP growth rate $(2.50 \%$ versus $2.23 \%$ ) than the group of industrial economies. Interestingly, the investment-to-output ratios are positively related to the growth rate of the output per capita in emerging markets (correlation coefficient of 0.75 ) but not among industrial economies (correlation coefficient of $-0.03 \%$ ). We observe in the following regression analysis that this negative relation between GDP per capita and investment-to-output ratios in industrial economies does not hold when we take into account the time dimension of the series.

The correlations between our three measures of globalization and the output per worker are always positive and on average larger for industrial economies. Figure 1 illustrates this positive relation more explicitly, for both samples of emerging and industrial economies we plot average per capita GDP growth rates against each of our three measures of trade (TO) and financial globalization (IFI and GEQ). In all six scattergrams the fitted regressions confirm the positive association between average GDP growth rates and trade and financial globalization. In Table 1, trade openness is the only measure of globalization that shows a higher average index among emerging economies (0.73) than across industrial countries (0.66). Financial globalization measures display positive correlation coefficients with output per capita and observe in general a stronger link in industrial economies: 0.35 against 0.01 for assets related globalization (IFI); 0.39 against 0.16 for equity related globalization (GEQ); and 0.41 against 0.25 for trade openness (TO). Indeed, the differences observed across our two measures of financial globalization confirm the importance of calculating the two alternative indexes.

\section{Methodology}


The main aim of this paper is not to improve upon the theoretical literature on economic growth but rather to use it along with the existing empirical literature to evaluate the influence of IT on income per capita growth. The basic estimable model employed here builds on Mankiw et al. (1992)'s seminal empirical application of the traditional textbook Solow model and on Islam (1995)'s reconsideration under panel data methods. Defined in logs, the empirical equation resulting from their analysis can be easily defined here as:

$$
\mathrm{Y}_{\mathrm{it}}=\beta_{0}+\beta_{1 \mathrm{i}}+\beta_{2} \mathrm{Z}_{\mathrm{it}}+\varepsilon_{\mathrm{it}}
$$

where $Y_{\text {it }}$ is the income per capita in country $i$ at time $t, \beta_{0}$ is an intercept term, $\beta_{1 \mathrm{i}}$ represents a vector of country specific factors, $\mathrm{Z}_{\mathrm{it}}$ is a vector of explanatory variable, which include the rate of population growth and the investment-to-output ratio $\left(\mathrm{I}_{t} / \mathrm{Y}_{\mathrm{t}}\right)$; and $\varepsilon_{i t}$ is the stochastic error term. From the traditional Solow (1956) model, we expect the two control variables in vector $\mathrm{Z}$ to have a positive impact on output per capita (i.e. $\beta_{2}$ $>0)$.

Kose et al. (2008) refer to the "globalization period” from 1986:3 to 2003:4 as the one in which there were dramatic increases in the volume of cross-border trade in both goods and assets. Presumably, these increasing flows of trade and capital have resulted on higher output growth ${ }^{7}$. Based on their evidence, we run the empirical models for several sample periods but do focus below on the post-1986 years, which should be more conducive to the globalization and inflation targeting procedures occurring jointly.

\footnotetext{
${ }^{7}$ See also Kose et al. (2006) for the “recent wave of financial globalization” as the one which got started in the mid-1980s.
} 
Kose et al. (2006) argue that using the sum of gross capital inflows and outflows as a ratio to national GDP yields a nice symmetry with the widely-used measure of trade openness, which is the sum of imports and exports as a ratio to GDP. However, such annual flows tend to be quite volatile and subject to measurement error. To mitigate these problems, one may use the comprehensive measures on financial globalization discussed in the preceding section, which capture financial openness in a global world, alongside the more traditional measure of trade openness proposed by Kose et al. (2006).

Our augmented empirical estimation which accounts for globalization can be thus defined as:

$$
Y_{i t}=\beta_{0}+\beta_{1 i}+\beta_{2} Z_{i t}+\beta_{3} G_{i t}+\varepsilon_{i t}
$$

where $\mathrm{G}$ is a vector containing any of our three measures of globalization: IFI, GEQ or TO. This empirical equation considers the influence that trade and financial globalization might have had on per capita output growth. We expect $\beta_{3}>0$ on the basis of more circulation of trade or financial flows helping the productive sector. The link between (2) and (1) is, in fact, very strong. Recent theoretical models explore the relationship between an index of capital/output ratio and economic growth. Beaudry and Collard (2006), for example, show that during a period of globalization we should observe an increase in the social returns to capital accumulation: $\beta_{3}$ should increase.

Finally, we account for the effects of adopting an IT regime on output growth by adding a dummy variable. That is 


$$
\mathrm{Y}_{\mathrm{it}}=\beta_{0}+\beta_{1 \mathrm{i}}+\beta_{2} \mathrm{Z}_{\mathrm{it}}+\beta_{3} \mathrm{G}_{\mathrm{it}}+\beta_{4} \mathrm{IT}_{\mathrm{it}}+\varepsilon_{\mathrm{it}}
$$

where IT is defined either as ITsoft or ITfull. As explained earlier, the former is a dummy variable which takes the value of 1 when a country adopts an incomplete IT regime and the later is a dummy variable which takes the value of 1 when a country starts a fullyfledged IT regime; if no IT regime is observed by a country the dummy variable takes values of zero. We expect $\beta_{4}>0$ (discipline effect of low inflation) or $\beta_{4}<0$ (too high output costs of inflation).

In addition to the static specifications presented above, we allow for a dynamic specification that contains lagged real GDP per capita as independent variable. For equation (3) the corresponding dynamic specification is defined as:

$$
\mathrm{Y}_{\mathrm{it}}=\beta_{0}+\beta_{1} \mathrm{Y}_{\mathrm{it}-1}+\beta_{2} \mathrm{Z}_{\mathrm{it}}+\beta_{3} \mathrm{G}_{\mathrm{it}}+\beta_{4} \mathrm{IT}_{\mathrm{it}}+\varepsilon_{\mathrm{it}}
$$

This dynamic specification allows for slower output adjustment and can be estimated using the dynamic panel methods developed by Arellano and Bond (1991). The first differentiation required by this method eliminates country specific effects and timeinvariant explanatory variables from equation (4). We define and estimate similar dynamic specifications for equations (1) and (2). The expected signs are as in the static model and a value of $\beta_{1}$ close to 1 would indicate a high degree of persistence. ${ }^{8}$

\footnotetext{
${ }^{8}$ As emphasized by Baltagi et al. (2008), the presence of the lagged dependent variable makes the estimated beta coefficients represent short-run effects. The long-run effects can be obtained by dividing each of the betas by $\left(1-\beta_{1}\right.$ ), where $\beta_{1}$ is the coefficient of the lagged dependent variable.
} 


\section{Results}

\subsection{Static Models}

Since the countries considered in our analysis are only a small subsample of a greater population, we employ random effects in estimating the initial static specifications. ${ }^{9}$ Tables 2 and 3 report estimates of equations (1)-(3) allowing for traditional income growth determinants, globalization controls and IT effects on income per capita for our samples of industrial and emerging market economies, respectively. Without controls for traditional growth determinants and globalization one may observe a distorted long-run relationship between output per capita and IT.

We report in Table 2 the results of estimating the static model in equations (1)-(3) for the sample of industrial countries. Here our findings are as follows. First, adding IT and globalization to the traditional textbook Solow equation exploited by Mankiw et. al. (1992) and Islam (1995), greatly improves the fit of the model (the $\mathrm{R}^{2}$ within increases from 0.127 to levels ranging from 0.584 to 0.853 ). Second, as in those studies by Mankiw et. al. (1992) and Islam (1995), there are positive and strongly significant coefficients for the rate of population growth and the investment-to-output ratio. Third, globalization helps economic growth in the long-run, with trade openness leading to higher output growth than financial globalization. An increase of $10 \%$ in the financial globalization index leads to about $2.6 \%$ increase in real per capita income for the more general IFI measure and to around $1.6 \%$ for GEQ. Meanwhile, we observe that per capita income increases between $6.6 \%$ and $7.5 \%$ when globalization is assumed to increase by $10 \%$

\footnotetext{
${ }^{9}$ For emerging and industrial economies, Hausman tests were inconclusive in more than half of the estimations presented; whenever conclusive, the tests suggested that random effects were the correct specification. In addition, we estimated the models in (1)-(3) by fixed effects finding no qualitative difference in the significance of our estimates.
} 
through an expansion of trade. Fourth, when the inflation targeting dummies are introduced, there are fairly positive values associated with the adoption of IT practices. Here, the coefficients vary in size according to the measure employed in the regression to control for globalization and depending on whether IT policies are partially adopted (ITsoft) or fully adopted (ITfull). Trade openness related estimations render the highest IT coefficients and, overall, ITfull noticeably presents larger and more significant coefficients than ITsoft. The latter finding suggests that adopting a full-fledged IT regime results in higher per capita income gains than adopting IT policies only partially.

[Table 2 here]

We report in Table 3 the results of estimating the static model for the sample of EMEs described previously. Most of the results are qualitatively similar to those we described above for industrial economies with one important difference. First, as before, controlling for globalization and IT improves the significance of the model considerably but not as much as in the estimates of industrial economies. The $\mathrm{R}^{2}$ within increases from 0.110 in equation (1) to levels between 0.348 and 0.462 in equations (2) and (3). Second, the expected positive effects of the investment-to-output ratio remain and, with some variations, they are close in magnitude to those observed for industrial economies. In contrast with the findings for industrial economies, for emerging markets population growth estimates present in all cases negative and very significant coefficients. This result is consistent with emerging markets high population growth rates being larger than those of their aggregate output, a situation that ultimately affects income per capita growth. Third, we observe again positive and very significant effects of globalization on income per capita. While the highest coefficients remain those related to trade (varying 
from 0.257 to 0.273 ), we observe that both, trade openness and financial globalization coefficients are in general smaller than those we obtained for industrial economies. This result suggests that industrial economies might have won more from globalization than emerging markets (at least) as measured by income per capita. Fourth, targeting inflation seems to be more relevant for emerging markets than for industrial economies. Coefficients for ITsoft and ITfull are generally larger than those for industrial economies. For the sample of emerging markets, we observe larger significance for both kinds of IT coefficients. This latter result suggests that emerging markets benefited more from IT than industrial economies as measured by the growth of their income per capita. Moreover, it also indicates that EMEs were able to benefit from adopting IT even when they decided not to implement all its principles completely.

[Table 3 here]

\subsection{Dynamic Models}

One important way to handle specification problems in our model is to allow for dynamic effects. Under such specification lagged real output conveys important information for the true patterns of per capita long-run output. We thus employ a model that takes into account output persistence alongside traditional growth controls and financial globalization measures in order to observe the true effects of IT on income per capita.

It is well known that the estimates of a dynamic model under OLS are biased because they contain lags of the dependent variable which are ultimately correlated with the error term. The Generalized Method of the Moments (GMM) estimator developed by 
Arellano and Bond (1991) solves this problem. Their method first differentiates static models presented in equations (1) to (3), removing time invariant explanatory variables. As in equation (4), the method produces dynamic equations that incorporate the lagged (endogenous) dependent variable. The endogenous explanatory variables are instrumented with suitable lags of their own. We employ in this case all available real per capita income lags as instruments. GMM estimations are said to be consistent if there is no second order autocorrelation in the residuals and the instruments employed are valid. The most common test employed to verify the validity of instruments in this GMM setup is the Sargan (1958) test of over-identifying restrictions.

Table 4 reports the estimation of equations (1)-(3) under a dynamic specification, similar to that in (4), for the sample of industrial economies. Arellano and Bond (1991) suggest employing one-step estimations for inference purposes as two-steps standard errors tend to be biased downward in small sample. In order to check the validity of the instruments, we report the Sargan test for the two-step estimations, which does not reject the null that the instruments are valid. However, the AB tests for the absence of secondorder serial correlation leads to rejecting the null of no second order serial correlation. We therefore report in parenthesis standard errors which are robust to autocorrelation and heteroskedasticity. The estimates suggest a very good overall fit with significant IT effects which are consistently robust across growth controls and globalization measures.

Several results are worth describing in the dynamic specification for industrial economies. First of all, lagged output always shows a positive and strongly significant impact on current output with a fairly high degree of persistence, ranging from about $82 \%$ to $86 \%$ depending on the specification. Second, the impact of the investment-to- 
output ratio remains positive and highly significant, albeit smaller in magnitude, once we control for persistence. Third, the empirical results in Table 4 also suggest that, once we control for output persistence effects, the financial globalization measures continue to have a positive effect on real output. The magnitude, however, is much smaller than in Table 2, ranging from 0.026 to 0.032 for IFI, from 0.016 to 0.019 for GEQ and 0.074 to 0.084 for TO; again, this latter indicator consistently shows the larger impact across our alternative specifications. Globalization coefficients are always statistically significant at the conventional $1 \%$ level. Fourth, IT continues to have small but positive effects on income per capita. Interestingly, and in contrast to the static model, once we account for dynamics, the soft IT regime shows positive and significant coefficients at the $10 \%$ level. This result suggests that IT might be beneficial for industrial economies even if its practices are not fully adopted. Similarly, ITfull remains positive and significant but with slightly smaller impact than under the static specification.

In order to search for long-run effects as discussed in footnote \#8, we divide each of the betas by $\left(1-\beta_{1}\right)$, where $\beta_{1}$ is the coefficient of the lagged dependent variable. This implies that the long-run ITsoft coefficients in Table 4 are, respectively, 0.068, 0.088, and 0.067 across columns (5) to (7). Similarly, the long-run ITfull coefficients in Table 4 are, respectively, $0.088,0.113$, and 0.081 across columns (8) to (10). Under the same set of controls, the static models imply that the implementation of a full-fledged IT regime by industrial countries helps marginally the output effects. Under dynamic models, however, the estimated long-run impact is higher by a substantial margin than the results reported in Table 2 for the static models.

[Table 4 here] 
Table 5 reports the results obtained from estimating equations (1)-(3) once we allow for dynamics in our sample of emerging market economies. The first point to notice in this Table is that, for all the estimates presented in columns (1) to (10), this time the $\mathrm{AB}$ serial correlation tests do not reject the null of no second order serial correlation. In addition, the Sargan tests for the two-step estimations do not reject the null hypothesis that the instruments employed are valid. Second, while highly significant, the impact of lagged income per capita is notably smaller than the one observed across industrial economies. A possible explanation for this is that expectations about output performance are stronger in stable industrial economies than in more volatile emerging markets. Third, with respect to traditional growth controls, as expected, investment-to-output ratios are highly significant and present the positive expected signs. The results for population coefficients are, however, mixed; with statistically significant and positive impact only in 3 of our 10 reported specifications and at the $10 \%$ level only. Fourth, financial globalization coefficients are positive and significant under all the specifications (i.e. not controlling for IT, controlling for ITsfot or ITfull) but the coefficients for trade openness are always negative and insignificant. This result clearly contrasts with those previously found for the static specification and the dynamic specification for industrial economies. Finally, with respect to the influence of IT, we observe no significant effect of ITsoft on output per capita once we control for dynamics. However, strict IT, as measures by ITfull, renders the positive expected sign and is statistically significant regardless of the globalization controls we employ in the estimations (IFI, GEQ or TO).

[Table 5 here] 
We conduct the same exercise as before in order to obtain the long-run effects in the dynamic models of Table 5 for emerging markets. The long-run ITsoft coefficients in Table 5 are not statistically significant across columns (5) to (7). On the other hand, the long-run ITfull coefficients in Table 5 are, respectively, 0.027, 0.036, and 0.041 across columns (8) to (10), which are lower than the values reported for the static models in Table 3. We do confirm, however, that adoption of a full-fledged IT regime by emerging markets helps marginally the output effects as well. Contrary to the industrial economies case, the estimated long-run impact in emerging markets is lower than the results reported in Table 3 for the static models. This is because the persistence coefficient of output is considerably lower in emerging markets economies than in industrial countries: $\beta_{1}$ is greater than 0.8 in Table 4 and $\beta_{1}$ is lower than 0.4 for most of the estimations in Table 5. While $\beta_{1}$ close to 1 would indicate near unit root behavior, a coefficient smaller than 0.5 would suggest that output dynamics is more predictable, which is certainly not the case in emerging markets. One alternative interpretation is that the discipline effect of the disinflation process of the last two decades in emerging markets (and industrial countries) has made the output benefits far outweigh the output costs of promoting high interest rates to reduce inflation and attract capital flows in a global world. ${ }^{10}$ However, due to the potential existence of long lags until the effects of greater credibility are fully observed in the real economy and the fact that emerging markets adopted IT regimes latter than industrial economies, the total effects of IT might have not been yet fully observed across emerging markets. This was precisely one of the arguments we posed to avoid assessing together industrial and emerging economies.

\footnotetext{
${ }^{10}$ This second channel is present in the interest rate defense put forward by Flood and Rose (2002), while the first is simply the result of conducting a more stringent monetary policy with the aim of achieving a particular target for inflation.
} 
In order to verify the robustness of our dynamic estimates, two important modifications were performed for both industrial and emerging economies. The first and most relevant was to investigate the possibility that globalization is endogenous. Under this scenario, economic growth leads to a higher level of financial flows across countries, which would invalidate the earlier assumption of globalization exogenous. Allowing for the endogeneity of globalization reports similar findings to those observed in Tables 4 and 5 for industrial and emerging economies. We conclude that this modification does not improve the fit of the model. Another possibility is to consider a longer degree of memory on our dynamic specification. Allowing for more than one lag of output in the dynamic specification, we do not find subsequent lags coefficients significant in our estimates. We omit these results for space constraints, as well as those for endogenous globalization but they are available from the authors upon request.

\section{Concluding Remarks}

We have examined in this paper the relationship between IT and real per capita income in two samples comprising 22 industrial and 33 emerging markets focusing on the post-1986 period. To the extent that economies have also benefited from globalization over the last couple of decades, we have also placed particular attention to the effects that trade openness and capital flows have brought to economic growth alongside explicit inflation targeting (IT). ${ }^{11}$ Overall, we found significant and positive effects of trade and financial globalization and IT on income growth. Once we control for traditional growth

\footnotetext{
${ }^{11}$ Rogoff (2004) lists a number of ways in which globalization has helped to reduce long run inflation. Among the most important channels listed, he suggest that greater competition has weakened the power of domestic monopolies and trade unions, leading to a permanent steeping up of the output-inflation trade-off faced by central banks. In our view, this makes examining the role of IT on output even more relevant.
} 
determinants and the recent globalization trends, the adoption of a fully-fledged IT regime results in higher output income per capita for industrial and emerging economies. However, under dynamic models the estimated long-run output impact of inflation targeting in emerging markets is lower than the results reported for the static models. This is because the persistence coefficient of output is considerably lower ( $\beta_{1}$ is lower than 0.4 ) in emerging markets economies than in industrial countries $\left(\beta_{1}\right.$ is greater than 0.8). While the evidence suggests that industrial economies gained more from globalization, emerging markets seem to have benefited from adopting inflation targets as well. One likely interpretation is that the disinflation process of the last two decades in emerging markets has made the output benefits far outweigh the output costs by setting high interest rates to attract capital flows in a global world but that the full effect of adopting the regime have not been fully felt by emerging markets as in industrial economies. We argue that this might be due to the long lags until the full effects of greater credibility are felt in the real economy and the fact that emerging markets adopted the regime much later than industrial economies.

Firm-level data in Schmukler and Vesperoni (2006), for example, examine the effects of globalization on the debt structure of firms operating in seven emerging economies. They find that with financial liberalization long-term debt decreases and the maturity structure shifts to the short-term. This sort of collateral benefit contrasts with the one in this paper and occurs at the microeconomic level. Another extension is to revisit the links between trade and financial openness in the empirical models. Aizenman (2008) proposes a mechanism through public finance in which trade opening leads to financial opening. These extensions, however, are left for further research. 


\section{References}

Aizenman, Joshua (2008). "On the Hidden Links between Financial and Trade Opening”, Journal of International Money and Finance 27: 372-386.

Albuquerque, Rui, Norman Loayza, and Luis Servén (2005). "World Market Integration through the Lens of Foreign Direct Investors”, Journal of International Economics 66: 267-295.

Alfaro, Laura and Eliza Hammel (2008). “Capital Flows and Capital Goods”, Journal of International Economics, forthcoming.

Alfaro, Laura, Areendam Chanda, Sebnem Kalemli-Ozcan, and Selin Sayek (2004). "FDI and Economic Growth: The Role of Local Financial Markets”, Journal of International Economics 64: 89-112.

Arellano, Manuel and Stephen Bond (1991). "Some Test of Specification for Panel Data: Monte Carlo Evidence and an Application to Employment Equations”, Review of Economic Studies 58 (2): 277-297.

Ball, Laurence, and Niamh Sheridan (2005). "Does Inflation Targeting Matter? In The Inflation Targeting Debate. NBER Studies in Business Cycles 32. Chicago: The University of Chicago Press.

Baltagi, Badi, Panicos Demetriades, and Siong Hook Law (2008). "Financial Development and Openness: Evidence from Panel Data”, Journal of Development Economics, forthcoming.

Beaudry, Paul and Fabrice Collard (2006). "Globalization, Returns to Accumulation and the World Distribution of Output”, Journal of Monetary Economics 53: 879-909.

Bekaert, Geert, Campbell Harvey, and Christian Lundblad (2005). "Does Financial Lberalization Spur Growth?”, Journal of Financial Economics 77: 3-55.

Bernanke, Ben (2003). “A Perspective on Inflation Targeting”, Business Economics 38 (3): 7-15.

Corbo, Vittorio, Oscar Landerretche and Klaus Schmidt-Hebbel (2002). “"Does Inflation Targeting Make a Difference" in Inflation Targeting: Design, Performance, Challenges, edited by Norman Loayza and Raimundo Soto, 221-269. Santiago: Central Bank of Chile.

Cordero, José Antonio (2007). “Economic Growth under Alternative Monetary Regimes: Inflation Targeting vs. Real Exchange Rate Targeting”, University of Massachusetts Amherst, Political Economy Research Institute Alternatives to Inflation Targeting No. 13, October. 
De Gregorio, José (1992). "Economic Growth in Latin America”, Journal of Development Economics 39: 59-84.

Dotsey, Michael (2006). “A Review of Inflation Targeting in Developed Countries”, Federal Reserve Bank of Philadelphia Business Review Q3: 10-20.

Edison, Hali, Michael Klein, Luca Ricci, and Torsten Slok (2004). "Capital Account Liberalization and Economic Performance: Survey and Synthesis”, IMF Staff Papers 51 (2): 220-256.

Evans, Martin and Viktoria Hnatkovska (2007). "International Financial Integration and the Real Economy”, IMF Staff Papers 54 (2): 220-269.

Flood, Robert, and Andrew Rose (2002). “Uncovered Interest Parity in Crisis”, IMF Staff Papers 49 (2): 252-266.

Fraga, Arminio, Ilan Goldfajn, and André Minella (2004). "Inflation Targeting in Emerging Market Economies," in Gertler, Mark and Kenneth Rogoff, eds., NBER Macroeconomics Annual, The MIT Press, Cambridge, MA, pp. 365-400.

Gonçalves, Carlos and Salles, João (2008). "Inflation Targeting in Emerging Economies: What Do the. Data Say?”, Journal of Development Economics 85 (1-2): 312-318.

Gupta, Rangan (2006). "Growth Effects of Inflation Targeting: The Role of Financial Sector Development”, University of Pretoria, Department of Economics Working Paper Series 2006-10, March.

Henry, Peter B. (2007). "Capital Account Liberalization: Theory, Evidence, and Speculation”, Journal of Economic Literature Vol. 45: 887-935.

Islam, Nazrul (1995). “Grow th Empirics: A Panel Data Approach”, Quarterly Journal of Economics 110 (4): 1127-1170.

Johnson, David (2002). "The Effects of Inflation Targeting on the Behavior of Expected Inflation: Evidence from an 11 Country Panel Data”, Journal of Monetary Economics 49 (8): 1521-38.

Kim, Jinill and Dale Henderson (2005). "Inflation Targeting and Nominal Income Growth Targeting: When and Why are they Suboptimal?”, Journal of Monetary Economics 52: 1463-1495.

Kose, M. Ayhan, Chrstopher Otrok, and Charles Whiteman (2008). "Understanding the Evolution of World Business Cycles”, Journal of International Economics, forthcoming. 
Kose, M. Ayhan, Eswar Prasad, Kenneth Rogoff, and Shang-Jin Wei (2006). "Financial Globalization: A Reappraisal”, IMF Working Paper 06/189.

Lane, Philip and Gian Maria Milesi-Ferretti (2007). "The External Wealth of Nations Mark II: Revised and Extended Estimates of Foreign Assets and Liabilities”, Journal of International Economics 73: 223-250.

Lin, Shu and Haichun Ye (2008) "Does Inflation Targeting Make a Difference in Developing Countries?”, Journal of Development Economics (forthcoming).

Mankiw, Gregory, David Romer, and David Weil (1992). "A Contribution to the Empirics of Economic Growth”, Quarterly Journal of Economics 107 (2): 407-437.

Mishkin, Frederic (2008). “Globalization and Financial Development”, Journal of Development Economics, forthcoming.

Mishkin, Frederic and Klaus, Schmidt-Hebbel (2007). "Does Inflation Targeting Makes a Difference”, National Bureau of Economic Research Working Paper 12786.

Mishkin, F. (2003). "Comments on Fraga, Goldfajn and Minella: Inflation Targeting in Emerging Market Economies"on Gertler, Mark and Kenneth Rogoff (Eds.) NBER Macroeconomics Annual 2003, The MIT Press, Cambridge, MA, p. 403-42.

Mishkin, Frederic (1999). "International Experience with Different Monetary Policy Regimes", Journal of Monetary Economics 43 (3): 579-605.

Newman, Manfred and Jurgen von Hagen (2002). “Does Inflation Targeting Matter?”, Federal Reserve Bank of St. Louis Review 84(4): 127-148.

Pollin, Robert and Andong Zhu (2005). "Inflation and Economic Growth: A CrossCountry Non-Linear Analysis”, University of Massachusetts Amherst, Political Economy Research Institute Working Paper Series No. 109, October.

Roger, Scott and Mark Stone (2005). “On Target?: The International Experience with Achieving Inflation Targets”, IMF Working Paper No. 05/163.

Rogoff, Kenneth (2004). “Globalization and Global Disinflation”, in Federal Reserve Bank of Kansas City. Monetary Policy and Uncertainty: Adapting to a Changing Economy, Papers and Proceedings of 2003 Jackson Hole Symposium.

Sachsida, Adolfo, Francisco G. Carneiro, and Paulo Loureiro (2003). "Does Greater Trade Openness Reduce Inflation? Further Evidence Using Panel Data Techniques”, Economics Letters 81: 315-319.

Sargan, J. D. (1958). “The Estimation of Economic Relationships using Instrumental Variables”, Econometrica 26: 393-414. 
Schmukler, Sergio and Esteban Vesperoni (2006). "Financial Globalization and Debt Maturity in Emerging Economies”, Journal of Development Economics, 79: 183-207.

Solow, Robert M. (1956): "A Contribution to the Theory of Economic Growth", Quarterly Journal of Economics 70(1): 65-94.

Svensson, Lars (2007). "Inflation Targeting", in Larry Blum and Steven Durlauf (editors), The New Palgrave Dictionary of Economics, $2^{\text {nd }}$ Edition.

Vega, Marco and Diego Winkelried (2005). "Inflation Targeting and Inflation Behavior: A Successful Story?”, International Journal of Central Banking 1 (3): 153-175.

Wynne, Mark and Erasmus Kersting (2007). “Openness and Inflation”, Federal Reserve Bank of Dallas Staff Papers No.2, April of 2007. 
Figure 1: Per-capita GDP Growth and Globalization
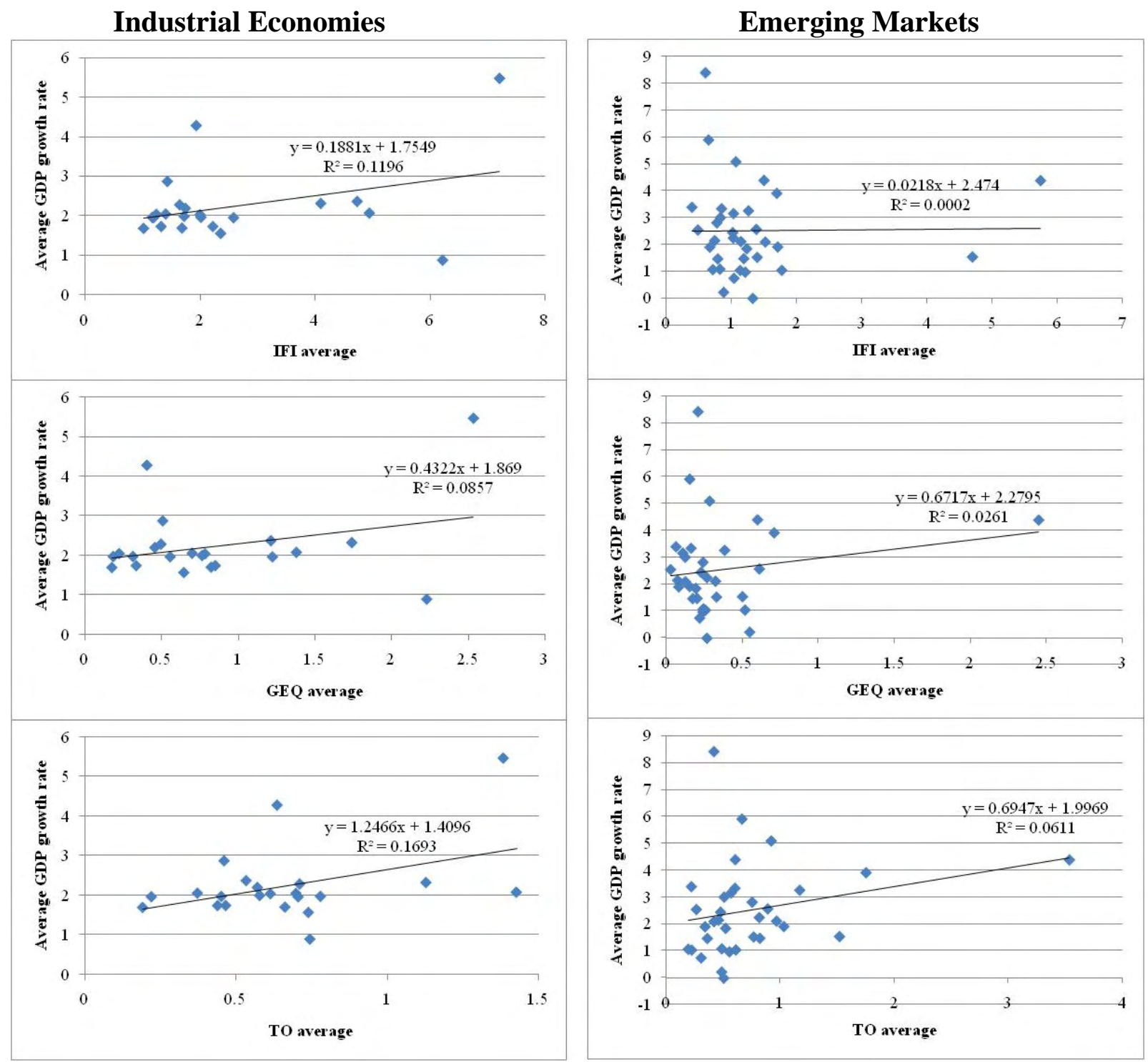
Table 1: Descriptive Statistics

\begin{tabular}{|c|c|c|c|c|c|c|c|c|c|c|c|c|c|c|c|c|c|}
\hline \multicolumn{9}{|c|}{ Emerging Market Economies } & \multicolumn{9}{|c|}{ Industrial C ountries } \\
\hline Country & $\mathbf{N}$ & ITsoft & ITfull & $(\mathrm{Y} / \mathrm{L})$ & $\mathbf{I} / \mathbf{Y}$ & IFI & GEQ & TO & Country & $\mathbf{N}$ & ITsoft & ITfull & $(\mathbf{Y} / \mathbf{L})$ & $\mathbf{I} / \mathbf{Y}$ & IF I & GEQ & TO \\
\hline Argentina & 19 & & & 1.04 & 17.13 & 1.13 & 0.26 & 0.22 & Australia & 19 & 1994 & 1994 & 2.05 & 24.33 & 1.40 & 0.70 & 0.37 \\
\hline Bangladesh & 19 & & & 2.55 & 18.07 & 0.48 & 0.03 & 0.26 & Austria & 19 & & & 1.97 & 22.12 & 2.02 & 0.31 & 0.78 \\
\hline Brazil & 19 & 1999 & 1999 & 1.07 & 18.60 & 0.71 & 0.25 & 0.19 & Belgium & 19 & & & 2.07 & 19.94 & 4.95 & 1.38 & 1.43 \\
\hline Bulgaria & 14 & & & 1.91 & 15.79 & 1.71 & 0.15 & 1.03 & Canada & 19 & 1991 & 1994 & 1.70 & 19.69 & 1.69 & 0.82 & 0.66 \\
\hline Chile & 19 & 1991 & 1999 & 4.40 & 22.40 & 1.50 & 0.60 & 0.61 & Denmark & 19 & & & 1.56 & 19.49 & 2.36 & 0.64 & 0.74 \\
\hline China & 19 & & & 8.41 & 32.58 & 0.60 & 0.21 & 0.42 & Finland & 19 & 1993 & 1993 & 2.03 & 20.87 & 2.00 & 0.78 & 0.61 \\
\hline Colombia & 19 & 1995 & 1999 & 1.47 & 18.24 & 0.79 & 0.17 & 0.36 & France & 19 & & & 1.74 & 19.31 & 2.23 & 0.85 & 0.47 \\
\hline Costa Rica & 19 & & & 2.25 & 19.11 & 1.03 & 0.27 & 0.82 & Germany & 19 & & & 2.19 & 20.69 & 1.75 & 0.46 & 0.57 \\
\hline Czech Republic & 11 & 1998 & 1998 & 3.26 & 28.49 & 1.26 & 0.38 & 1.17 & Greece & 19 & & & 1.97 & 19.92 & 1.17 & 0.18 & 0.45 \\
\hline Dominican Republic & 19 & & & 2.82 & 20.26 & 0.78 & 0.24 & 0.75 & Iceland & 19 & 2001 & 2001 & 2.04 & 20.16 & 1.24 & 0.22 & 0.70 \\
\hline Ecuador & 19 & & & 0.97 & 20.00 & 1.21 & 0.24 & 0.55 & Ireland & 19 & & & 5.47 & 19.24 & 7.21 & 2.54 & 1.39 \\
\hline Egypt & 19 & & & 2.45 & 21.27 & 1.02 & 0.23 & 0.48 & Italy & 19 & & & 1.74 & 20.19 & 1.32 & 0.33 & 0.44 \\
\hline El Salvador & 14 & & & 3.34 & 16.53 & 0.85 & 0.16 & 0.60 & Japan & 19 & & & 1.69 & 27.56 & 1.02 & 0.18 & 0.19 \\
\hline Hungary & 19 & 2001 & 2001 & 2.11 & 21.89 & 1.14 & 0.32 & 0.97 & Netherlands & 19 & & & 2.32 & 21.40 & 4.10 & 1.74 & 1.13 \\
\hline India & 19 & & & 3.39 & 22.85 & 0.39 & 0.06 & 0.22 & New Zealand & 19 & 1990 & 1991 & 1.99 & 20.66 & 1.72 & 0.76 & 0.58 \\
\hline Indonesia & 19 & & & 3.16 & 24.83 & 1.03 & 0.11 & 0.57 & Norway & 19 & 2001 & 2001 & 2.28 & 21.34 & 1.65 & 0.50 & 0.71 \\
\hline Israel & 19 & 1992 & 1997 & 1.53 & 20.55 & 1.39 & 0.33 & 0.77 & Portugal & 19 & & & 4.28 & 25.00 & 1.94 & 0.40 & 0.64 \\
\hline Korea & 19 & 1998 & 1998 & 5.90 & 32.92 & 0.65 & 0.15 & 0.66 & Spain & 19 & 1994 & 1995 & 2.87 & 21.12 & 1.43 & 0.51 & 0.46 \\
\hline Malaysia & 19 & & & 3.91 & 30.62 & 1.69 & 0.71 & 1.75 & Sweden & 19 & 1993 & 1995 & 1.96 & 18.12 & 2.59 & 1.22 & 0.71 \\
\hline Mexico & 19 & 1995 & 1999 & 1.08 & 19.09 & 0.82 & 0.24 & 0.49 & Switzerland & 19 & 1993 & 1995 & 0.89 & 24.13 & 6.22 & 2.23 & 0.75 \\
\hline Morocco & 19 & & & 1.85 & 22.19 & 1.23 & 0.19 & 0.52 & United Kingd om & 19 & 1992 & 1992 & 2.37 & 17.76 & 4.74 & 1.21 & 0.53 \\
\hline Nigeria & 18 & & & 1.04 & 8.64 & 1.77 & 0.52 & 0.61 & United States & 19 & & & 1.96 & 18.75 & 1.19 & 0.56 & 0.22 \\
\hline Pakistan & 19 & & & 1.90 & 16.65 & 0.67 & 0.08 & 0.34 & & & & & & & & & \\
\hline Panama & 19 & & & 1.54 & 17.10 & 4.69 & 0.50 & 1.52 & Total/Average & 418 & & & 2.23 & 20.99 & 2.54 & 0.84 & 0.66 \\
\hline Peru & 19 & 1994 & 2002 & 0.75 & 19.48 & 1.04 & 0.22 & 0.31 & $\operatorname{Corr}(\mathrm{Y} / \mathrm{L}, \mathrm{X})$ & & & & & -0.03 & 0.35 & 0.29 & 0.41 \\
\hline Philippines & 19 & 1995 & 2002 & 1.48 & 20.14 & 1.19 & 0.20 & 0.82 & & & & & & & & & \\
\hline Poland & 19 & 1998 & 1998 & 3.01 & 20.12 & 0.83 & 0.12 & 0.51 & & & & & & & & & \\
\hline Singapore & 19 & & & 4.39 & 32.53 & 5.74 & 2.45 & 3.54 & & & & & & & & & \\
\hline South Africa & 19 & 2000 & 2000 & 0.22 & 16.71 & 0.88 & 0.55 & 0.49 & & & & & & & & & \\
\hline Thailand & 19 & 2000 & 2000 & 5.09 & 31.39 & 1.07 & 0.28 & 0.92 & & & & & & & & & \\
\hline Tunisia & 19 & & & 2.57 & 24.34 & 1.38 & 0.61 & 0.89 & & & & & & & & & \\
\hline Turkey & 17 & & & 2.15 & 22.63 & 0.74 & 0.07 & 0.46 & & & & & & & & & \\
\hline Uruguay & 19 & & & 2.10 & 12.84 & 1.52 & 0.12 & 0.42 & & & & & & & & & \\
\hline Venezuela & 19 & & & 0.00 & 20.19 & 1.33 & 0.27 & 0.50 & & & & & & & & & \\
\hline Total/Average & 624 & & & 2.50 & 21.36 & 1.30 & 0.33 & 0.73 & & & & & & & & & \\
\hline $\operatorname{Corr}(\mathrm{Y} / \mathrm{L}, \mathrm{X})$ & & & & & 0.75 & 0.01 & 0.16 & 0.25 & & & & & & & & & \\
\hline
\end{tabular}

Notes: For the correlation estimates X represents the explanatory variables listed on each column: (I/Y), IFI, GEQ and TO. Bulgaria’s GDP is only available since 1991. The Czech Republic, El Salvador and Nigeria also present some missing data. 
Table 2: Random Effects Model of GDP Per Capita: Post-1986 Years for Industrial Economies

\begin{tabular}{|c|c|c|c|c|c|c|c|c|c|c|}
\hline & (1) & (2) & (3) & (4) & (5) & (6) & (7) & (8) & (9) & (10) \\
\hline $\ln (\mathrm{I} / \mathrm{Y})$ & $\begin{array}{l}-0.017 \\
(0.060)\end{array}$ & $\begin{array}{c}0.229 * * * \\
(0.026)\end{array}$ & $\begin{array}{c}0.245^{* * *} \\
(0.030)\end{array}$ & $\begin{array}{c}0.210^{* * *} \\
(0.043)\end{array}$ & $\begin{array}{c}0.238 * * * \\
(0.028)\end{array}$ & $\begin{array}{c}0.264 * * * \\
(0.032)\end{array}$ & $\begin{array}{c}0.285^{* * *} \\
(0.046)\end{array}$ & $\begin{array}{c}0.245^{* * *} \\
(0.028)\end{array}$ & $\begin{array}{c}0.268 * * * \\
(0.031)\end{array}$ & $\begin{array}{c}0.271 * * * \\
(0.045)\end{array}$ \\
\hline$\Delta \mathrm{L} / \mathrm{L}$ & $\begin{array}{c}19.068 * * * \\
(2.560)\end{array}$ & $\begin{array}{c}5.247 * * * \\
(1.128)\end{array}$ & $\begin{array}{c}9.923 * * * \\
(1.246)\end{array}$ & $\begin{array}{c}14.699 * * * \\
(1.789)\end{array}$ & $\begin{array}{c}5.366 * * * \\
(1.137)\end{array}$ & $\begin{array}{c}10.071 * * * \\
(1.244)\end{array}$ & $\begin{array}{c}14.917^{* * *} \\
(1.751)\end{array}$ & $\begin{array}{c}5.546 * * * \\
(1.139)\end{array}$ & $\begin{array}{c}10.217 * * * \\
(1.243)\end{array}$ & $\begin{array}{c}15.141^{* * *} \\
(1.756)\end{array}$ \\
\hline $\ln (\mathrm{IFI})$ & & $\begin{array}{c}0.266 * * * \\
(0.006)\end{array}$ & & & $\begin{array}{c}0.263 * * * \\
(0.007)\end{array}$ & & & $\begin{array}{c}0.260 * * * \\
(0.007)\end{array}$ & & \\
\hline $\ln (\mathrm{GEQ})$ & & & $\begin{array}{c}0.162^{* * *} \\
(0.004)\end{array}$ & & & $\begin{array}{c}0.158^{* * *} * \\
(0.005)\end{array}$ & & & $\begin{array}{c}0.156^{* * *} \\
(0.005)\end{array}$ & \\
\hline $\ln (\mathrm{TO})$ & & & & $\begin{array}{c}0.751^{* * *} \\
(0.037)\end{array}$ & & & $\begin{array}{c}0.672 * * * \\
(0.041)\end{array}$ & & & $\begin{array}{c}0.664 * * * \\
(0.042)\end{array}$ \\
\hline ITsoft & & & & & $\begin{array}{c}0.009 \\
(0.011)\end{array}$ & $\begin{array}{c}0.019 \\
(0.012)\end{array}$ & $\begin{array}{c}0.074^{* * *} \\
(0.018)\end{array}$ & & & \\
\hline ITfull & & & & & & & & $\begin{array}{l}0.018^{*} \\
(0.011)\end{array}$ & $\begin{array}{c}0.026^{* *} \\
(0.012)\end{array}$ & $\begin{array}{c}0.071 * * * \\
(0.017)\end{array}$ \\
\hline cons & $\begin{array}{c}12.276^{* * *} \\
(0.452)\end{array}$ & $\begin{array}{c}11.437 * * * \\
(0.342)\end{array}$ & $\begin{array}{c}11.644^{* * *} \\
(0.328)\end{array}$ & $\begin{array}{c}12.010^{* * * *} \\
(0.433)\end{array}$ & $\begin{array}{c}11.407^{* * *} \\
(0.347)\end{array}$ & $\begin{array}{c}11.578 * * * \\
(0.338)\end{array}$ & $\begin{array}{c}11.721^{* * *} \\
(0.440)\end{array}$ & $\begin{array}{c}11.386 * * * \\
(0.346)\end{array}$ & $\begin{array}{c}11.562 * * * \\
(0.337)\end{array}$ & $\begin{array}{c}11.761^{* * *} \\
(0.437)\end{array}$ \\
\hline $\mathrm{R}^{2}$ within & 0.127 & 0.852 & 0.813 & 0.584 & 0.852 & 0.814 & 0.602 & 0.853 & 0.816 & 0.601 \\
\hline
\end{tabular}

Notes: Logarithms are taken on output, globalization measures, and investment/output series. Standard errors are in parenthesis. The $\beta_{0}$ and $\beta_{1 i}$ 's terms are included but are not reported. Hausman tests support the random effects model as explained in the text. The symbols *, **, and *** refer to levels of significance of $10 \%$, $5 \%$, and $1 \%$, respectively. 
Table 3: Random Effects Model of GDP Per Capita: Post-1986 Years for Emerging Economies

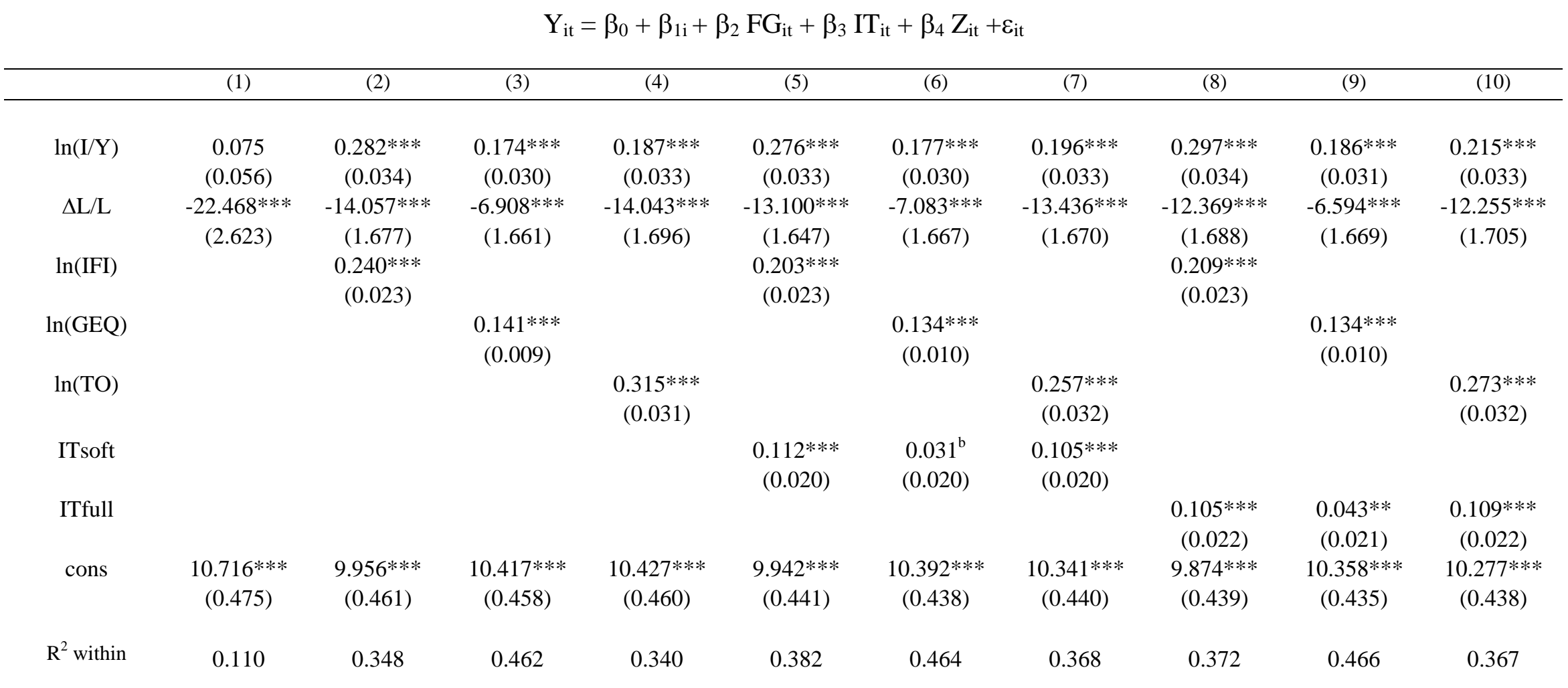

Notes: Logarithms are taken on output, financial globalization, and investment/output series. Standard errors are reported in parenthesis. The $\beta_{0}$ and $\beta_{1 \mathrm{i}}$ 's terms are included but are not reported. Hausman tests support the random effects model as explained in the text. The symbols *, **, and ${ }^{* * *}$ refer to levels of significance of $10 \%$, $5 \%$, and $1 \%$, respectively; ; ${ }^{\text {b }}$ implies significance at the $14 \%$ level. 
Table 4: Dynamic Model (Arellano-Bond) of GDP Per Capita: Post-1986 for Industrial Economies

\begin{tabular}{|c|c|c|c|c|c|c|c|c|c|c|}
\hline & (1) & (2) & (3) & (4) & (5) & (6) & (7) & (8) & (9) & (10) \\
\hline $\ln \left(Y_{t-1}\right)$ & $\begin{array}{c}0.869 * * * \\
(0.050)\end{array}$ & $\begin{array}{c}0.817 * * * \\
(0.038)\end{array}$ & $\begin{array}{c}0.849 * * * \\
(0.046)\end{array}$ & $\begin{array}{c}0.848 * * * \\
(0.037)\end{array}$ & $\begin{array}{c}0.824 * * * \\
(0.037)\end{array}$ & $\begin{array}{c}0.852 * * * \\
(0.045)\end{array}$ & $\begin{array}{c}0.851^{* * *} \\
(0.036)\end{array}$ & $\begin{array}{c}0.829 * * * \\
(0.035)\end{array}$ & $\begin{array}{c}0.858 * * * \\
(0.043)\end{array}$ & $\begin{array}{c}0.852^{* * *} \\
(0.037)\end{array}$ \\
\hline $\ln (\mathrm{I} / \mathrm{Y})$ & $\begin{array}{c}0.064 * * * \\
(0.017)\end{array}$ & $\begin{array}{c}0.076 * * * \\
(0.017)\end{array}$ & $\begin{array}{c}0.069 * * * \\
(0.015)\end{array}$ & $\begin{array}{c}0.076^{* * * *} \\
(0.018)\end{array}$ & $\begin{array}{c}0.086 * * * \\
(0.017)\end{array}$ & $\begin{array}{c}0.082 * * * \\
(0.016)\end{array}$ & $\begin{array}{c}0.085^{* * *} \\
(0.018)\end{array}$ & $\begin{array}{c}0.084 * * * \\
(0.015)\end{array}$ & $\begin{array}{c}0.082^{* * *} \\
(0.015)\end{array}$ & $\begin{array}{c}0.083 * * * \\
(0.016)\end{array}$ \\
\hline$\Delta \mathrm{L} / \mathrm{L}$ & $\begin{array}{c}0.166 \\
(0.804)\end{array}$ & $\begin{array}{c}-0.100 \\
(0.654)\end{array}$ & $\begin{array}{c}0.045 \\
(0.734)\end{array}$ & $\begin{array}{c}0.305 \\
(0.605)\end{array}$ & $\begin{array}{c}-0.011 \\
(0.651)\end{array}$ & $\begin{array}{c}0.117 \\
(0.720)\end{array}$ & $\begin{array}{c}0.344 \\
(0.618)\end{array}$ & $\begin{array}{c}0.057 \\
(0.617)\end{array}$ & $\begin{array}{c}0.146 \\
(0.673)\end{array}$ & $\begin{array}{c}0.374 \\
(0.612)\end{array}$ \\
\hline $\ln (\mathrm{IFI})$ & & $\begin{array}{c}0.032 * * * \\
(0.008)\end{array}$ & & & $\begin{array}{c}0.028 * * * \\
(0.007)\end{array}$ & & & $\begin{array}{c}0.026 * * * \\
(0.007)\end{array}$ & & \\
\hline $\ln (\mathrm{GEQ})$ & & & $\begin{array}{c}0.019 * * * \\
(0.003)\end{array}$ & & & $\begin{array}{c}0.017 * * * \\
(0.003)\end{array}$ & & & $\begin{array}{c}0.016^{* * *} \\
(0.003)\end{array}$ & \\
\hline $\ln (\mathrm{TO})$ & & & & $\begin{array}{c}0.084^{* * *} \\
(0.017)\end{array}$ & & & $\begin{array}{c}0.077 * * * \\
(0.016)\end{array}$ & & & $\begin{array}{c}0.074 * * * \\
(0.017)\end{array}$ \\
\hline ITsoft & & & & & $\begin{array}{c}0.012 * * \\
(0.005)\end{array}$ & $\begin{array}{c}0.013^{* * *} \\
(0.005)\end{array}$ & $\begin{array}{c}0.010 * * \\
(0.005)\end{array}$ & & & \\
\hline ITfull & & & & & & & & $\begin{array}{c}0.015^{* * *} \\
(0.005)\end{array}$ & $\begin{array}{c}0.016^{* * *} \\
(0.004)\end{array}$ & $\begin{array}{c}0.012 * * * \\
(0.004)\end{array}$ \\
\hline cons & $\begin{array}{c}0.003^{* * *} \\
(0.001)\end{array}$ & $\begin{array}{c}0.002 * * \\
(0.001)\end{array}$ & $\begin{array}{c}0.001 \\
(0.001)\end{array}$ & $\begin{array}{c}0.002^{* * *} \\
(0.001)\end{array}$ & $\begin{array}{c}0.002 * * \\
(0.001)\end{array}$ & $\begin{array}{c}0.001 \\
(0.001)\end{array}$ & $\begin{array}{c}0.002 * * \\
(0.001)\end{array}$ & $\begin{array}{c}0.002 * * \\
(0.001)\end{array}$ & $\begin{array}{c}0.001 \\
(0.001)\end{array}$ & $\begin{array}{c}0.002 * * \\
(0.001)\end{array}$ \\
\hline Sargan Test & $\begin{array}{c}20.97 \\
{[1]}\end{array}$ & $\begin{array}{c}20.01 \\
{[1]}\end{array}$ & $\begin{array}{c}20.27 \\
{[1]}\end{array}$ & $\begin{array}{c}20.97 \\
{[1]}\end{array}$ & $\begin{array}{c}20.03 \\
{[1]}\end{array}$ & $\begin{array}{c}19.91 \\
{[1]}\end{array}$ & $\begin{array}{c}19.75 \\
{[1]}\end{array}$ & $\begin{array}{c}20.16 \\
{[1]}\end{array}$ & $\begin{array}{c}19.54 \\
{[1]}\end{array}$ & $\begin{array}{c}19.86 \\
{[1]}\end{array}$ \\
\hline $\mathrm{AB}(1)$ & $\begin{array}{c}-2.23 \\
(0.056)\end{array}$ & $\begin{array}{c}-2.22 \\
(0.026)\end{array}$ & $\begin{array}{c}-2.38 \\
(0.017)\end{array}$ & $\begin{array}{c}-2.1 \\
(0.036)\end{array}$ & $\begin{array}{c}-2.24 \\
(0.025)\end{array}$ & $\begin{array}{c}-2.39 \\
(0.017)\end{array}$ & $\begin{array}{c}-2.13 \\
(0.017)\end{array}$ & $\begin{array}{c}-2.26 \\
(0.024)\end{array}$ & $\begin{array}{c}-2.4 \\
(0.017)\end{array}$ & $\begin{array}{c}-2.14 \\
(0.033)\end{array}$ \\
\hline $\mathrm{AB}(2)$ & $\begin{array}{c}-2.54 \\
(0.011)\end{array}$ & $\begin{array}{c}-2.12 \\
(0.034)\end{array}$ & $\begin{array}{c}-2.06 \\
(0.039)\end{array}$ & $\begin{array}{c}-2.21 \\
(0.027)\end{array}$ & $\begin{array}{c}-2.11 \\
(0.035)\end{array}$ & $\begin{array}{c}-2.05 \\
(0.040)\end{array}$ & $\begin{array}{c}-2.19 \\
(0.039)\end{array}$ & $\begin{array}{c}-2.23 \\
(0.026)\end{array}$ & $\begin{array}{c}-2.17 \\
(0.030)\end{array}$ & $\begin{array}{c}-2.27 \\
(0.023)\end{array}$ \\
\hline
\end{tabular}

Notes: Logarithms are taken on output, globalization, and investment/output series. The Table reports the first-step estimators of the Arellano and Bond (1992) procedure. Robust standard errors are reported in parenthesis below the coefficients for each explanatory variable. The symbols *, **, and *** refer to levels of significance of $10 \%, 5 \%$, and $1 \%$, respectively. The Sargan test reports that under the null the overidentified restrictions are valid. AB (1) and AB (2) correspond to the Arellano-Bond test for serial correlation, under the null of no autocorrelation (p-values are reported in parenthesis below the AB statistics). 
Table 5: Dynamic Model (Arellano-Bond) of GDP Per Capita: Post-1986 for Emerging Economies

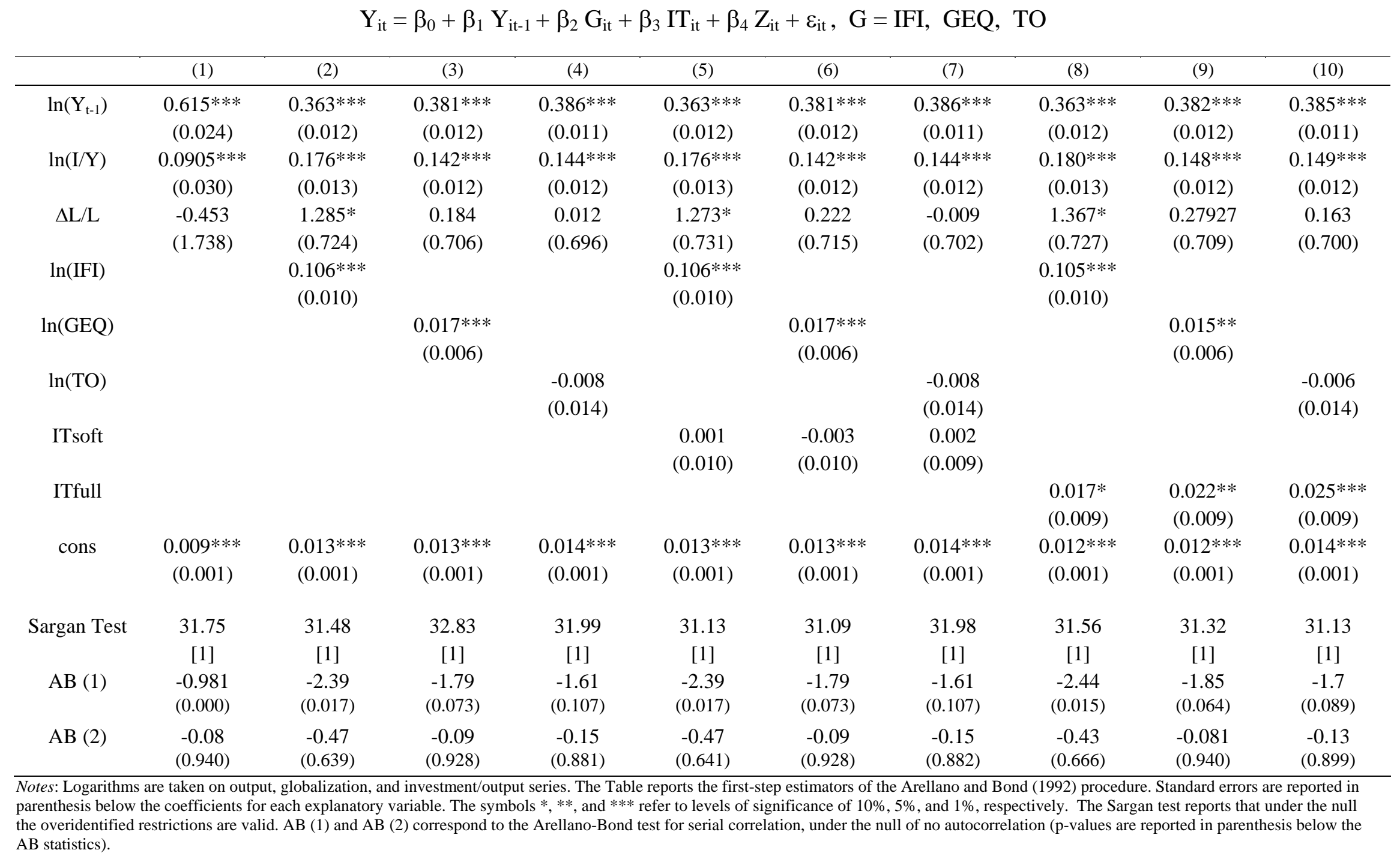

